Rev. Latino-Am. Enfermagem 2019;27:e3111

DOI: 10.1590/1518-8345.2619.3111

www.eerp.usp.br/rlae

\title{
Prevalence of malaria relapse: systematic review with meta-analysis
}

\author{
Talita Lima do Nascimento ${ }^{1,2}$ \\ Suleima Pedroza Vasconcelos ${ }^{1}$ \\ Yara Peres ${ }^{3}$ \\ Mirla Jéssica Sampaio de Oliveira ${ }^{4}$ \\ Monica Taminato ${ }^{2}$ \\ Káren Mendes Jorge de Souza ${ }^{2}$
}

Objective: systematic review with a meta-analysis of the prevalence of malaria relapse. Method: it consisted in a search for cross-sectional studies, carried out in three databases, without application of filters. A total of 1,924 articles were identified, selected based on eligibility criteria. The selection was made in pairs from the reading of the titles, abstracts and text. The metaanalysis was performed with a statistical program. Results: a sample of 1,308 patients with malaria, ranging from 70 to 586 patients in the study. Relapse was estimated at $0.47 \%$, with a $95 \%$ confidence interval and $99.04 \%$ of squared $i$. In the included studies, the prevalence of relapse ranged from $17.00 \%$ to $92.85 \%$. The result of the meta-analysis is considered relevant, despite the heterogeneity. Conclusion: relapse is a phenomenon that can contribute to the maintenance of the endemicity of malaria in the world and to introduce it in non-affected areas. In addition, there is the need for advancement in the production of knowledge regarding this disease, to qualify the research methods on prevalence.

Descriptors: Malaria; Recurrence; Prevalence; Neglected Diseases; Public Health Nursing.

\footnotetext{
${ }^{1}$ Universidade Federal do Acre, Centro de Ciências da Saúde e do Desporto, Rio Branco, AC, Brazil.

2 Universidade Federal de São Paulo, Escola Paulista de Enfermagem, São Paulo, SP, Brazil.

3 Secretaria Municipal de Saúde de Pauiní, Unidade Básica Saúde José Roberto, Pauiní, AM, Brazil.

${ }^{4}$ Secretaria Municipal de Saúde de Cruzeiro do Sul, Unidade de Saúde da Família 25 de agosto, Cruzeiro do Sul, AC, Brazil.
}

\section{How to cite this article}

Nascimento TL, Vasconcelos SP, Peres Y, Oliveira MJS, Taminato M, Souza KMJ. Prevalence of malaria relapse: systematic review with meta-analysis. Rev. Latino-Am. Enfermagem. 2019;27:e3111. [Access ‘_+子_; ]; Available in: DOI: http://dx.doi.org/10.1590/1518-8345.2619.3111. month day year 


\section{Introduction}

Malaria is recognized by the World Health Organization (WHO) as an important public health problem because of its high prevalence and because it is related to low socioeconomic development ${ }^{(1)}$. The tropical and subtropical areas of the planet are the most affected, most notably Southeast Asia, the Amazon and Africa. This latter has $80 \%$ of the total cases and deaths by malaria in the world(2).

The disease affects, especially, poor populations with difficult access to health services, in poor housing and work conditions. High incidence is also observed in areas of disorderly occupation of territories and in the migration from the rural to the periphery of $\operatorname{cities}^{(3)}$.

Malaria is considered a neglected tropical disease whose management and clinical management need to be more effective in the field of public health(4). Add to this the problem of disease relapse, which has contributed to its endemicity. Thus, it is worth reflecting which challenges and coping strategies are most feasible for malaria control, as well as the role of nursing in identifying and developing alternatives to deal with disease relapse ${ }^{(4)}$

Understanding the biological cycle of malaria is important in understanding the phenomenon of relapse. The disease is caused by protozoa of the genus Plasmodium of four species, and the most prevalent infection is by Plasmodium vivax, which is also the type responsible for most cases of relapse, since it develops latent forms in the liver cells called hypnozoites, which may stay inactive for weeks ${ }^{(5-6)}$.

Malaria relapse can be defined as the recurrence of asexual parasitemia after drug treatment and the finding of its negativity in a given period of time, due to a variety of factors ${ }^{(7)}$.

According to the scientific literature, this clinical picture can occur for several reasons, among which the following stand out: lack of patient adherence to treatment, prescription of therapeutic regimens that do not combat the tissue phase of the cycle, resistance of Plasmodium to antimalarial drugs and reactivation of the hypnozoites ${ }^{(8)}$.

The phenomenon of relapse has important consequences for the patient, the community and the health services, as it contributes to the maintenance of the number of cases reported, thus increasing public health costs and expenses( ${ }^{(9)}$.

Investigating and measuring the prevalence rate of malaria relapse is an important indicator for health services and for disease control programs. This information can help nurses in the planning of interventions, guide managers in the application of financial resources, and foster research needed to explain the factors that determine the phenomenon at the local level and its endemic permanence ${ }^{(5,10)}$. In addition, this may be an important data for conducting economic evaluations studies in malaria control programs.

The objective of this study was to perform a systematic review, with meta-analysis, of observational studies that estimated the prevalence of malaria relapse.

\section{Method}

This is a systematic review with a meta-analysis of observational studies, conducted according to the recommendations of the Preferred Reporting Items for Systematic Reviews and Meta-Analyzes (PRISMA) (11). The study was guided by a structured question in the format of structured clinical question, as follows: population of interest or health problem $(P)$, which corresponds to patients with malaria; intervention (I): malaria control programs; comparator (C): not applicable; outcome (O): prevalence of relapse; and study (S): observational studies.

The search and selection of scientific evidence for the review was carried out in the databases Medical Literature Analysis and Retrieval System Online (Medline) via National Library of Medicine (Pubmed), Scientific and Technical Literature of Latin America and the Caribbean (Lilacs) and Cochrane Library. The bases were chosen based on the wide coverage of the Pubmed and Cochrane Library and on the location of studies carried out in the Americas, endemic for malaria, in the case of Lilacs.

Figure 1 describes the search strategy used in each database.

The search in the databases was carried out in August 2016. No filters were applied so that we could identify all the articles available in the databases and reduce the risk of publication bias. The eligibility criteria were being cross-sectional observational studies and having outcome relapse prevalence as outcome.

The reading and selection of the articles was carried out by two reviewers independently, starting by the titles, followed by the abstracts and full texts. In the selection of the titles, we included all those that presented one of the following terms: relapse, prevalence, malaria and Plasmodium. When the application of the eligibility criteria was not sufficient to establish whether or not the article would be included in a phase, it was retained for reading the abstract. The last phase of the selection was made by reading the full text of the articles. 


\begin{tabular}{|c|c|c|}
\hline Database & Search Terms & Result \\
\hline Medline $^{*}$ & $\begin{array}{c}\left.\left.\text { (“malaria”[MeSH Terms }{ }^{\dagger}\right] \text { OR "malaria"[All Fields]) AND ((“malaria”[MeSH Terms }{ }^{\dagger}\right] \\
\text { OR "malaria"[All Fields]) AND (“recurrence"[MeSH Terms'] OR "recurrence”[All } \\
\text { Fields] OR "relapse"[All Fields])) }\end{array}$ & 1,286 articles \\
\hline Lilacs $\pi$ & $\begin{array}{c}\text { ((malária AND estudos epidemiológicos) OR (recaídas) AND (instance:"regional”) } \\
\left.\text { AND ( } \mathrm{db}^{++}:(“ L i l a c s " I)\right)\end{array}$ & 550 articles \\
\hline Cochrane Library & malaria relapse & 88 articles \\
\hline Total & & 1,924 \\
\hline
\end{tabular}

*Medline - Medical Literature Analysis and Retrieval System Online; †MeSH Terms - Terms of Medical Subject Headings; Lilacs - Latin America and Caribbean Literature in Health Sciences; $++d b$ - database

Figure 1 - Search strategy by database

In the seven selected studies, an analysis was carried out to verify the methodological quality, using the checklist STRENBE (Strengthening the Reporting of Observational Studies in Epidemiology), as they were cross-sectional studies(12). Twenty-two items are referred to in this instrument, which should be reported, improving methodological rigor in this type of design. At this stage, two studies were excluded for not presenting key elements to the study design and because the source for obtaining the data to estimate the prevalence rate was secondary. In the five eligible studies, when analyzing the checklist, weaknesses were detected in the description of the measures to reduce risk of bias.

Data extraction from the included studies was performed in pairs independently, using a previously planned spreadsheet, containing the following information: author, year of publication, period of data collection, study location, age group, method used for case detection, sample ( $n$ ) and prevalence of outcome.
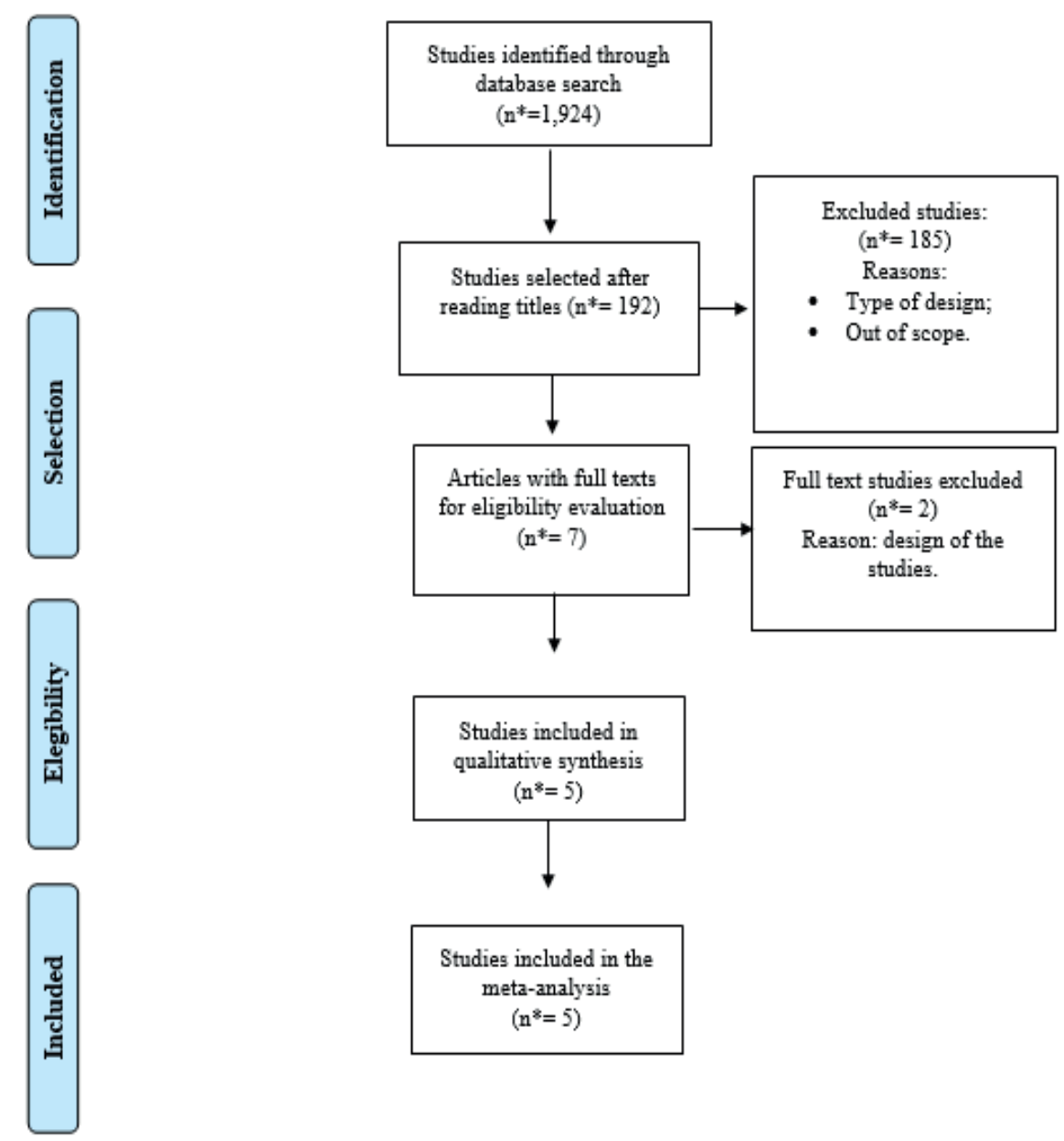

*n - Sample

Figure 2 - Study selection flowchart 


\begin{tabular}{|c|c|c|c|c|c|c|c|}
\hline Author/Year & Period & Country & Age & $\begin{array}{l}\text { Detection } \\
\text { method }\end{array}$ & Sample & $\begin{array}{l}\text { Prevalence of } \\
\text { Relapse }\end{array}$ & $95 \% \mathrm{Cl}^{*}$ \\
\hline $\begin{array}{c}\text { Depali Savargaonkar } \\
\text { et al. } 2015^{(15)}\end{array}$ & $\begin{array}{c}2011 \\
- \\
2014\end{array}$ & India & Unreported & $\begin{array}{l}\text { Clinical and } \\
\text { laboratory test }\end{array}$ & 426 & $18.74 \%$ & $(0.152,0.226)$ \\
\hline $\begin{array}{l}\text { Gonzalez- Ceron et } \\
\text { al. } 2013^{(16)}\end{array}$ & $\begin{array}{c}1998 \\
- \\
2008\end{array}$ & Mexico & Unreported & Laboratory test & 70 & $92.85 \%$ & $(0.854,0.979)$ \\
\hline Pedro et al. $2012^{(17)}$ & $\begin{array}{c}2005 \\
- \\
2011\end{array}$ & Brazil & $\geq 12$ & $\begin{array}{l}\text { Clinical and } \\
\text { laboratory test }\end{array}$ & 89 & $39.60 \%$ & $(0.294,0.497)$ \\
\hline $\begin{array}{l}\text { Orjuela-Sanchez et } \\
\text { al. } 2009^{(18)}\end{array}$ & $\begin{array}{c}2004 \\
- \\
2006\end{array}$ & Brazil & $\geq 75$ & $\begin{array}{l}\text { Clinical and } \\
\text { laboratory test }\end{array}$ & 586 & $65.40 \%$ & $(0.615,0.692)$ \\
\hline $\begin{array}{l}\text { Manandhar etl al } \\
2013^{(19)}\end{array}$ & $\begin{array}{c}2010 \\
- \\
2011\end{array}$ & Nepal & Unreported & Laboratory test & 137 & $17.00 \%$ & $(0.110,0.235)$ \\
\hline
\end{tabular}

${ }^{*} \mathrm{CI}$ - Confidence Interval

Figure 3 - Data extracted from the studies included in the systematic review

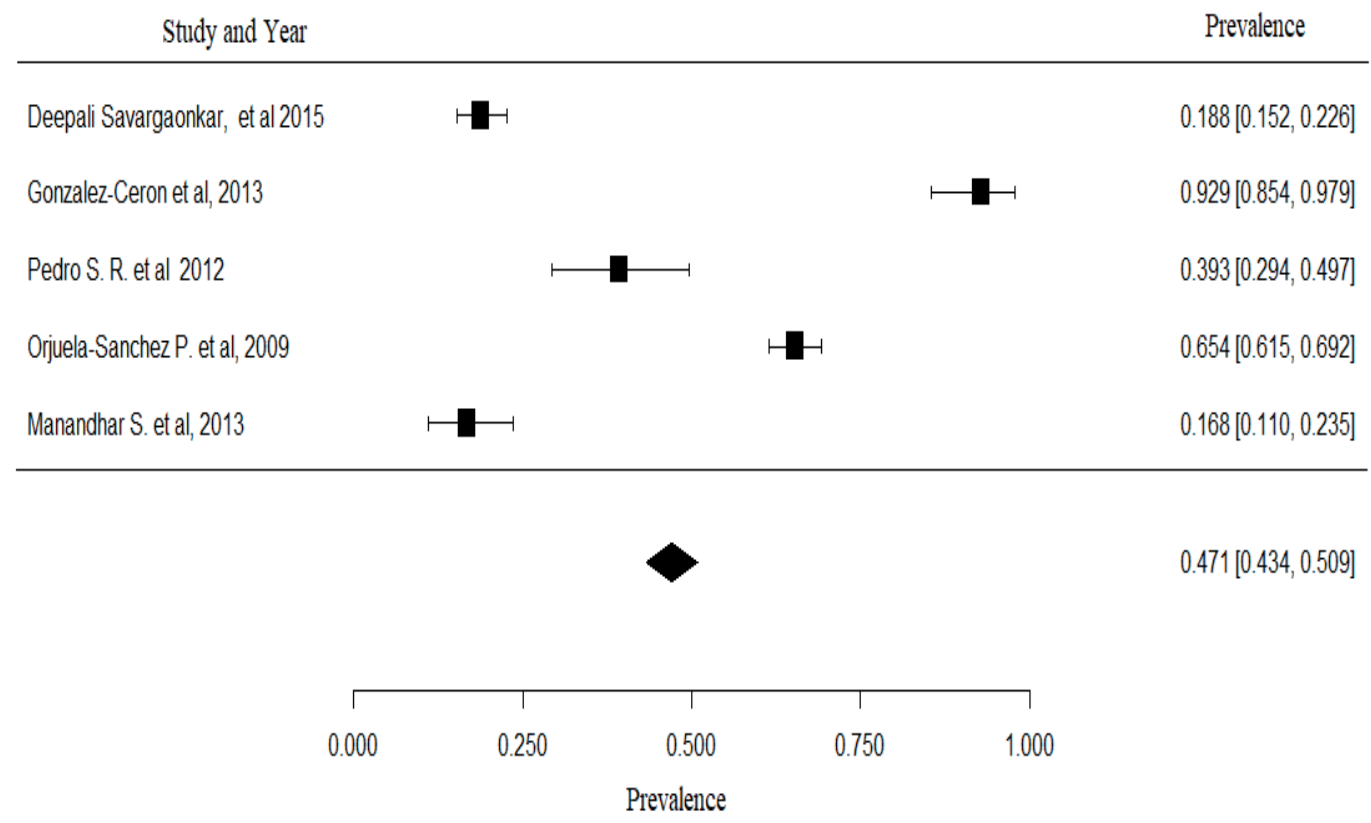

Figure 4 - Meta-analysis of the prevalence of relapse

Meta-analysis is a statistical analysis that combines and synthesizes results from several studies, and makes it possible to explain the differences in their findings. The measure of summarization of the results for the meta-analysis was the prevalence rate of the five included studies. The statistical analysis was performed using the statistical software R Metafor. The calculation of heterogeneity was performed by $i$ squared $\left(\mathrm{I}^{2}\right)$, adopting fixed effects model, considering that all the studies had the same outcome. Analyzes in which $\mathrm{I}^{2}$ presents value $>70 \%$ can be considered with high heterogeneity ${ }^{(13-14)}$.
There was no need to approve the study project in the Research Ethics Committee because it was a systematic review with search for scientific evidence published in databases.

\section{Results}

Five studies were included for the review and meta-analysis, according to Figure 2 . All articles that did not present prevalence data of relapse were excluded because they were out of the scope of the research or because of the type of design. 
Data were extracted from the studies selected for review, according to Figure 3. Two studies were excluded due to the use of secondary data obtained from health surveillance information systems.

The sample of the five studies totaled 1,308 people, ranging from 70 to 586 patients with malaria diagnosed by different types of Plasmodium, with the majority of cases being Plasmodium vivax.

The prevalence of relapse was 0.47 and ranged from 17 to $92.85 \%$, with a confidence interval of $95 \%{ }^{(15-19)}$. The methodological procedures for recruitment and confirmation of relapse cases varied among the studies, and all five presented laboratory test as standard.

The meta-analysis expresses the prevalence of relapse, according to Figure 4, with a confidence interval of $95 \%$.

The heterogeneity has $\mathrm{I}^{2}$ of $99.04 \%$, with $\mathrm{p}<0.001$ and $95 \%$ confidence interval $(0.434,0.509)$. The difference between the studies can be considered high.

\section{Discussion}

The results show that malaria relapse is a worrisome phenomenon, since it can contribute to the disease remaining endemic in the affected areas and introduce it in non-affected areas, which can exacerbate the epidemiological picture and generate impacts on economic and social aspects ${ }^{(16)}$.

A study carried out in the city of Porto Velho, in the state of Rondônia, Brazil, indicated that the risk of relapse was estimated at 45.1/100 inhabitants and that this risk can be considered a high rate for a city of this size when compared to the rate for the Amazon region, estimated at $20.8 \%{ }^{(8)}$. In Ethiopia, a study showed that $77 \%$ of secondary malaria cases are due to relapses ${ }^{(20)}$.

It is most likely that the cause of relapse is the reactivation of the hypnozoites and the great capacity of Plasmodium vivax to adapt biologically, with phenotypic changes $^{(7)}$.

Also related to the biological factor of the parasite, a study carried out in Nepal estimated the prevalence rate of relapse at $17 \%$, stating that there may be a relationship between the specific genotypes of Plasmodium vivax, which may differ between the different geographical regions, considering the biological aspects of the immunity of specific populations(19).

Knowing the prevalence of relapse is crucial for public health, since it extends the possibilities of management by malaria control programs, allowing the understanding of the magnitude of the disease and, therefore, the adequate planning of actions by services, conferring greater effectiveness to health interventions. From the epidemiological point of view, it allows users who remain with the disease, thus being sources of infection, to be identified in a timely manner, interrupting the transmission cycle ${ }^{(21)}$.

In order to verify the prevalence of relapse, it is necessary that Cure Slide Verification (CSV) be performed after the end of treatment. This is, therefore, a technology that should integrate the actions of the programs, since it is an important indicator for the health services for being able point operational problems of epidemiological surveillance, inform which users are sources of infection, "besides being useful to differentiate a new infection (new case)" from a relapse ${ }^{(21)}$.

Because it is a neglected disease, including its financing, there is an intimate relationship between its occurrence and the social and economic development of the affected region. In countries with poor populations and less access to goods and services, vulnerability to relapse is greater due to, among other reasons, limitations on financial resources for disease control programs. Thus, it can be observed that social inequality patterns determine and are determined by the occurrence of malaria(22).

The disorderly occupation of territories by poor populations in search of subsistence, without other alternatives, or by groups with economic interests in the extraction of natural resources has been associated to the maintenance of the prevalence of neglected diseases like malaria. In this sense, the role of nurses is of utmost importance, since in some territories this is the only health professional that is present and capable of establishing control and prevention measures ${ }^{(4)}$.

The result found in the meta-analysis of the prevalence of relapse shows high heterogeneity, 99.04\%. This is due to the fact that the original studies present significant differences in their methodological designs. There is still a lack of methodological standardization for these types of studies, even when appropriate techniques are applied for proper and judicious selection and eligibility. The attempt to reduce publication bias in the meta-analysis was based on the extensive search in the databases ${ }^{(14)}$.

In Brazil, the National Malaria Control Program (PNCM in Portuguese) aims to reduce the incidence and severity of malaria and, consequently, the number of hospitalizations and deaths resulting therefrom, with an increasing emphasis on studies related to the systematization of vector control processes and actions. Faced with the challenges imposed by the current times, it is necessary to "make efforts to acquire knowledge and skills to take care of new paradigms that contemplate the entirety of the individual and their insertion and inseparability with the environment ${ }^{(23)}$.

Malaria relapse can increase disease management costs and affect the effectiveness of disease control 
programs. Considering its relation with poverty and underdevelopment, one can question how the poorest countries control new cases and relapse, since some studies indicate that economic and social development is directly associated with the prevalence of neglected diseases $^{(24)}$.

Malaria relapse is an important indicator of the outcome of the control programs, since it can increase disease management costs and affect the effectiveness of their actions. Another important aspect is that the relapse rate points to the need to monitor the resistance of the parasite to antimalarials and can help to promote changes in drug policies.

A more specific look at relapse cases is also necessary due to its relevance for the maintenance of the endemic disease, its high prevalence rate and consequent challenges for health surveillance ${ }^{(25)}$.

The study presents limitations because the gray literature was not consulted and because of its high heterogeneity.

The results of this work can be used as a basis for conducting research on economic evaluation of health technologies to intervene in malaria.

\section{Conclusion}

Malaria, even with advances in technology and epidemiological science, remains a challenge for public health. The phenomenon of malaria relapse has contributed to the fact that its endemicity has not changed and compromises the effectiveness of programs aimed at its control or even eradication.

The prevalence of relapse is concerning not only from the clinical point of view, in which the damage to the patient is directly expressed in their non-cure, their lack of conditions to work and consequently in the prejudice of their quality of life.

In addition to this factor, there are also the slow and insufficient progress in the development of therapeutic alternatives and other technologies that are capable of braking the transmission of the disease, the financial investments also insufficient for the new cases and for relapse cases, human action on the environment and the biological capacity of the etiological agent to adapt and produce genetic changes that challenge the combat of the disease.

The estimated prevalence in this study points to the need to establish measures that go beyond the field of care, including the area of professional training, and scientific research and development. Outlining policies and programs to control neglected diseases, such as malaria, require the understanding of the magnitude of phenomena such as relapse so that they can be truly effective, meeting the needs of the population.

\section{Acknowledgements}

Thanks to the master Marcos Vinícius Malveira de Lima for performing the statistical analysis of the study.

\section{References}

1. Mitano F, Ventura CAA, Palha PF. Health and development in Sub-Saharan Africa: a reflection focusing on Mozambique. Physis: revista de saúde coletiva. [Internet]. 2016 jan [cited Set 20, 2017]; 26(3):9015. Available from: http://www.scielo.br/pdf/physis/ v26n3/0103-7331-physis-26-03-00901.pdf

2. Monasar D, Nuthulaganti T, Kruger PS, Mabuza A, Rasiswi ES, Benson FG, et al. Malaria control in South Africa 2000-2010 beyond MDG6. Malar J. [Internet]. 2012 [cited Mar 16, 2016]; 11:294-300. Available from: https://www.ncbi.nlm.nih.gov/pmc/articles/ PMC3502494/pdf/1475-2875-11-294.pdf

3. Reiners AAO, Bilo BB, Azevedo RCS, Fontes CJF, Ferreira RG, Souza TG, et al. Studies on adherence to malaria treatment. Enferm Glob. [Internet]. 2013 [cited Mar 16, 2016]; 32: 304-19. Available from: http:// scielo.isciii.es/pdf/eg/v12n32/pt_revisiones2.pdf

4. Blood-Siegfried J, Zeantoe GC, Evans LG, Bondo J, Forstner JR, Wood K. The impact of nurses on neglected tropical disease management. Public Health Nurs. [Internet]. 2015 [cited Feb 20, 2017]; 32(6): 680-701. Available from: http://onlinelibrary. wiley.com/doi/10.1111/phn.12149/epdfr3_ referer=wol\&tracking_action=preview_click\&show_ checkout=1\&purchase_referrer $=w w w . n c b i . n I m . n i h$. gov\&purchase_site_license $=$ LICENSE_DENIED

5. Reiners AAO, Azevedo RCS, Ricci HA, Souza TG. User adherence and reactions to malaria treatment: implications for health education. Texto Contexto Enferm. [Internet]. 2010 [cited Mar 21, 2017]; 19(3): 536-44. Available from: http://www.scielo.br/pdf/tce/ v19n3/a16v19n3.pdf

6. White MT, Karl S, Battle KE, Hay SI, Muelle I, Ghani AC. Modelling the contribuition of the hypnozoite reservoir to plasmodium vivax transmission. Elife. [Internet]. 2014 [cited Apr 4, 2017]; 3: 1-19. Available from: https:// www.ncbi.nlm.nih.gov/pmc/articles/PMC4270097/pdf/ elife04692.pdf

7. Rajapakse S, Rodrigo C, Fernando SD. Tafenoquine for preventing relapse in people with plasmodium vivax malaria (Review). Cochrane Database Syst Rev. [Internet]. 2015 [cited Mar 21, 2017]; (4):1-55. Available from: https://www.ncbi.nlm.nih.gov/pmc/ articles/PMC4468925/pdf/CD010458-0001.pdf

8. Simões LR, Alves ER Jr, Silva DR, Gomes LT, Nery AF, Fontes CJF. Factors associated with recurrent plasmodium vivax malaria in Porto Velho, Rondônia state, Brazil, 2009. Cad Saúde Pública. [Internet]. 2014 [cited Apr 4, 
2017]; 30(7):1-15. Available from: http://www.scielo. $\mathrm{br} / \mathrm{pdf} / \mathrm{csp} / \mathrm{v30n7/0102-311X-csp-30-7-1403.pdf}$

9. Almeida ED, Rodrigues LCS, Vieira JLF. Estimates of adherence to treatment of vivax malaria. Malar J. [Internet]. 2014 [cited Apr 6, 2017]; 13: 321-7. Available from: https://www.ncbi.nlm.nih.gov/pmc/ articles/PMC4141083/pdf/12936_2014_Article_3354. pdf

10. França TCC, Santos MG, Figueroa-Villar JD. Malaria: Historical aspects and chemoterapy. Qim nova. [Internet]. 2008 [cited Apr 7, 2017]; 31(5):1271-8. Available from: http://www.scielo.br/pdf/qn/v31n5/ a60v31n5.pdf

11. Moher D, Liberati A, Tefzlaff J, Altman DG. Preferred reporting items for sistematyc reviews and metaanalyses: the PRISMA statement. PloS med. [Internet]. 2009 [cited Mar 6, 2017]; 6(7): 1-6. Available from: https://www.ncbi.nlm.nih.gov/pmc/articles/ PMC2707599/pdf/pmed.1000097.pdf

12. Vandenbroucke JP, Elm EV, Altmam DG, Gotzsche PC, Mulrow CD, Pocock SJ, et al. Strengthning the reporting of observacional studies in epidemiology (STROBE): explanation and elaboration. PloS Med. [Internet]. 2007 [cited Mar 6, 2017]; 18(6):805835. Available from: http://journals.Iww.com/epidem/ fulltext/2007/11000/Strengthening_the_Reporting_of_ Observational.28.aspx

13. Viechtbauer W. Conducting meta-analyses in R with the metafor package. Journal of Statistical Software. [Internet]. 2010 [cited Apr 12, 2017]; 36(3):1- 48. Available from: http://www.jstatsoft.org/v36/i03/

14. Pereira MG, Galvão TF. Heterogeneity and publication bias in systematic reviews. Epidemiol. ser saúde. [Internet]. 2014 [cited Mar 22, 2017]; 23(4):7758. Available from: http://www.scielo.br/pdf/ress/ v23n4/2237-9622-ress-23-04-00775.pdf

15. Depali S, Nagpal BN, Srivastana B, Anvikar AR, Valecha $N$. The footprints of relapsing malaria in southwest Delhi, India. J. vector borne dis. [Internet]. 2015 [cited Mar 04, 2017]; 52:287-92. Available from: http://www.mrcindia.org/journal/issues/524287.pdf

16. Gonzalez-Ceron L, Mu J, Santillán F, Joy D, Sandoval MA, Camas G, et al. Molecular and epidemiological characterization of Plasmodium vivax recurrent infections in southern Mexico. Paras. vectors. [Internet].2013 [cited Mar 4, 2017]; 6(1):10920. Avaible from: https://parasitesandvectors. biomedcentral.com/track/pdf/10.1186/1756-3305-6109 ? site $=$ parasitesandvectors. biomedcentral.com

17. Pedro RS, Guaraldo L, Campos DP, Costa AP, Daniel-Ribeiro CT, Brasil P. Plasmodium vivax malaria relapses at a travel medicine centre in Rio de Janeiro, a non-endemic area in Brazil. Malar J.[Internet]. 2012 [cited Mar 5, 2017]; 11(1):245 - 251. Available from: https://malariajournal.biomedcentral.com/track/ pdf/10.1186/1475-2875-11-245?site=malariajournal. biomedcentral.com

18. Orjuela-Sanchez P, Silva NS, Silva-Nunes M, Ferreira MU. Recurrent parasitemias and population dynamics of plasmodium vivax polymorphisms in Rural Amazonia. Am. j. trop. med. hyg. [Internet]. 2009 [cited Mar 5, 2017]; 81(6): 961-8. Available from: http://www.ajtmh. org/docserver/fulltext/14761645/81/6/961.pdfexpires= $1508872989 \&$ id $=$ id\&accname $=$ guest $\&$ checksum $=F 4501$ 9F5C97B73AFB7261648A3524868

19. Manandhar S, Bhusal CL, Ghimire U, Singh SP, Karmacharya DB, Dixit SM. A study on relapse/ re-infection rate of Plasmodium vivax malaria and identification of the predominant genotypes of P. vivax in two endemic districts of Nepal. Malar J. [Internet]. 2013 [cited Mar 13, 2017]; 12(1):324-30. Available from: https://www.ncbi.nlm.nih.gov/pmc/articles/ PMC3848640/pdf/1475-2875-12-324.pdf

20. Golassa L, White MT. Population-level estimates of the proportion of Plasmodium vivax blood-stage infections attributable to relapses among febrile patients attending Adama Malaria Diagnostic Centre, East Shoa Zone, Oromia, Ethiopia. Malar J. [Internet]. 2017 Jul 27 [cited 2018 May 15];16(1):301-11. Available from: https://malariajournal.biomedcentral.com/ articles/10.1186/s12936-017-1944-3

21. Parisi ÉV. Surveillance, prevention and control of malaria in Palmas, Tocantins, Brazil, from 2000 to 2013. Hygeia [Internet]. 2014 Jun [cited 2018 May 15];10(18):190-296. Available from: http://www.seer. ufu.br/index.php/hygeia

22. Tusting LS, Willey B, Lucas H, Thompson J, Kafy HT, Smith R, et al. Socioeconomic development as an intervention against malaria: a systematic review and meta-analysis. Lancet [Internet]. 2013 Sep 14 [cited 2018 May 15];382(9896):963-72. Available from: https://www.thelancet.com/pdfs/journals/lancet/ PIIS0140-6736(13)60851-X.pdf

23. Boulos M, Amato V Neto, Dutra AP, Santi SM, Shiroma M. Analysis of the frequency of relapses due to malaria caused by Plasmodium vivax in a non endemic area (São Paulo, Brazil). Rev Inst Med Trop São Paulo. [Internet]. 1991 [cited Mar 7, 2017]; 33(2): 143-146. Available from: http://www.scielo.br/pdf/rimtsp/v33n2/ a09v33n2.pdf

24. Wang SQ, Li YC, Zhang ZM, Wang GZ, Hum XM, Qualls WA, et al. Prevention measures and socioeconomic development result in a decrease in malaria in Hainan, China. Malar. j. [Internet]. 2014 [cited Mar 15, 2017]; 13(1):362-7. Available from: https://malariajournal.biomedcentral.com/track/ pdf/10.1186/1475-2875-13-362?site=malariajournal. biomedcentral.com 
25. Vieira GD, Gim KNM, Zaqueo GM, Alves TC, Katsuragawa TH, Basano SA, et al. Reduction of incidence and relapse or recrudescence cases of malaria in the western region of the Brazilian Amazon. J Infect Dev Ctries. [Internet]. 2014 [cited Mar 5, 2017]; 8(9):11817. Available from:https://jidc.org/index.php/journal/ article/view/25212083/11 Creative Commons (CC BY).

This license lets others distribute, remix, tweak, and build upon your work, even commercially, as long as they credit you for the original creation. This is the most accommodating of licenses offered. Recommended for maximum dissemination and use of licensed materials. 